\title{
URGENSI KONTRAK KERJA YANG BERKEADILAN SEBAGAI UPAYA PERLINDUNGAN HUKUM RAHASIA DAGANG
}

\author{
Rizki Nur Annisa, Adi Sulistiyono, Emmy Latifah \\ Program Magister Ilmu Hukum, Universitas Sebelas Maret \\ Jalan Ir. Sutami No. 36A, Jebres, Kota Surakarta, Jawa Tengah \\ rizkinurannisao8@gmail.com
}

\begin{abstract}
Trade secret is "heart" of business continuity. Hence, the business people try to apply strict protection because trade secret has vital role in business. Trade secret violations in Indonesia are mostly undertaken by the employees due to the weakness of legal protection and the lack of employees consciousness in fulfilling their responsible. Employment contract, which can bind the parties, becomes an effort to give limitation of rights and obligations. Therefore, this research uses normative legal research method which aims to study the urgency of fair employment contract as an effort to protect the trade secret legally. The research finding shows that employment contract is able to become the alternative of trade secret legal protection effort. The reason is; the rights and obligations of the employees which are mutually regulated make the trade secret can be optimally protected.
\end{abstract}

Keywords : trade secret, employment contract, employees, fair

\begin{abstract}
Abstrak
Rahasia dagang merupakan 'jantungnya' keberlangsungan sebuah bisnis. Oleh karena rahasia dagang mempunyai posisi yang sangat vital, pelaku usaha berusaha melakukan proteksi sangat ketat. Pelanggaran rahasia dagang di Indonesia sebagian besar dilakukan oleh karyawan, dikarenakan lemahnya kesadaran karyawan untuk memenuhi kewajibannya dan akibat lemahnya perlindungan hukum. Dibutuhkan kontrak kerja yang mengikat Karyawan dan Pemilik Rahasia dagang untuk memberi batasan hak dan kewajiban serta sanksi sebagai bentuk perlindungan hukum rahasia dagang. Untuk mencapai tujuan itu digunakan metode penelitian hukum normatif untuk mengkaji urgensi kontrak kerja yang berkeadilan sebagai upaya perlindungan hukum rahasia dagang. Hasil penelitian ini menunjukkan bahwa dengan adanya kontrak kerja yang adil dapat menjadi alternatif upaya perlindungan hukum rahasia dagang; dikarenakan hak dan kewajiban karyawan yang diatur secara mutual menjadikan rahasia dagang dapat dilindungi secara optimal.
\end{abstract}

Kata kunci : rahasia dagang, kontrak kerja, perlindungan hukum, adil

A. Pendahuluan

Rahasia dagang memiliki peran yang sangat vital dalam sebuah usaha, karena merupakan salah satu penopang berkembang dan bertahannya suatu usaha. Rahasia dagang adalah suatu informasi yang di dalamnya terdapat nilai ekonomis. Berdasarkan Pasal 1 ayat (1) UndangUndang Nomor 30 Tahun 2000 tentang Rahasia Dagang, sebuah informasi dapat dikatakan sebagai rahasia dagang apabila tidak diketahui umum, mempunyai nilai 
ekonomi karena memiliki kegunaan dalam kegiatan usaha, dan atas informasi tersebut dijaga kerahasiaannya oleh pemilik rahasia dagang. Selanjutnya, informasi yang berkaitan dengan rahasia dagang sendiri, berdasarkan Pasal 2 Undang-Undang Nomor 30 Tahun 2000 tentang Rahasia Dagang mencakup banyak hal yaitu metode produksi; metode pengolahan; metode penjualan; atau informasi lainnya di bidang teknologi dan atau bisnis yang bernilai ekonomi dan tidak diketahui oleh masyarakat umum. Rahasia dagang yang tidak terlindungi secara baik dapat menimbulkan dampak negatif bagi berlangsungnya suatu usaha karena suatu usaha erat kaitannya dengan persaingan usaha (Mustikarini, 2016). Pengelolaan rahasia dagang melibatkan pemilik rahasia dagang dan juga pihak lain seperti pihak ketiga pemegang hak rahasia dagang serta karyawan yang berhubungan langsung dengan rahasia dagang.

Undang-Undang Nomor 30 Tahun 2000 tentang Rahasia Dagang mengatur perlindungan hukum yang berkaitan dengan terjadinya pelanggaran rahasia dagang dengan sanksi perdata dan pidana. Sanksi perdata yang terdapat dalam Pasal 11 yang isinya:

1. Pemegang Hak Rahasia Dagang atau penerima Lisensi dapat menggugat siapa pun yang dengan sengaja dan tanpa hak melakukan perbuatan sebagaimana dimaksud dalam Pasal 4, berupa:

a. Gugatan ganti rugi; dan/atau

b. Penghentian semua perbuatan sebagaimana dimaksud dalam Pasal 4.

2. Gugatan sebagaimana dimaksud dalam ayat (1) diajukan ke Pengadilan Negeri.

Sanksi pidana dari adanya pelanggaran rahasia dagang diatur dalam Pasal 17 Undang-Undang Nomor 30 tahun 2000 tentang Rahasia Dagang yang isinya:

(1) Barangsiapa dengan sengaja dan tanpa hak menggunakan Rahasia Dagang pihak lain atau melakukan perbuatan sebagaimana dimaksud dalam Pasal 13 atau Pasal 14 dipidana dengan pidana penjara paling lama 2 (dua) tahun dan denda paling banyak Rp 300.000.000,00 (tiga ratus juta rupiah).

(2) Tindak pidana sebagaimana dimaksud dalam ayat (1) merupakan delik aduan. Adanya sanksi perdata maupun pidana tidak cukup menghindarkan adanya pelanggaran rahasia dagang. Ditinjau dari kasus pelanggaran rahasia dagang yang sampai di pengadilan, hanya terdapat enam kasus di mana tiga kasus merupakan ranah hukum pidana dan tiga kasus masuk ke dalam ranah hukum perdata. Hal ini dikarenakan masyarakat Indonesia 
umumnya belum terlalu sadar akan pentingnya rahasia dagang. Dari enam kasus pelanggaran rahasia dagang empat kasus merupakan pelanggaran yang disebabkan oleh karyawan, 1 kasus secara tidak langsung juga melibatkan karyawan dan satu kasus lagi tidak terbukti adanya pelanggaran rahasia dagang. Dari bukti tersebut dapat diketahui bahwa salah satu pelanggaran rahasia dagang yang banyak terjadi di Indonesia dilakukan atau melibatkan karyawan. Secara ekonomis, pelanggaran rahasia dagang sangat merugikan pemilik hak rahasia dagang (Paat, 2013). Kesadaran karyawan yang turut menjaga rahasia dagang masih lemah. Hubungan kerja yang banyak terjadi hanya secara lisan. Hal ini terjadi karena tidak jelasnya pola hubungan hukum antara pemilik hak rahasia dagang dengan karyawan. Ketidakjelasan pola hubungan ini yang sering kali menyebabkan terjadinya pelanggaran rahasia dagang yang dilakukan oleh karyawan. Pola hubungan hukum antara pemilik rahasia dagang dengan karyawan tidak diatur pula dalam Undang-Undang Nomor 30 Tahun 2000 tentang Rahasia Dagang.

Dalam banyak kasus, karyawan merupakan pelaku terbanyak atas pelanggaran rahasia dagang. Kasus yang dapat dijadikan contoh adalah pelanggaran rahasia dagang terjadi pada Restoran Sunda di daerah Bintaro Jaya, Jakarta Selatan
(Saputro, 2016). Pemilik Restauran Sunda tersebut tidak memiliki kompetensi pada bidang kuliner sehingga semua racikan bumbu dipercayakan pada kepala koki (head chef). Permasalahan mulai muncul ketika rumah makan mulai ramai dan kepala koki mulai melakukan hal-hal yang menurut pemilik restoran dianggap "tidak sewajarnya", seperti meminta kenaikan gaji, menuntut penambahan pegawai, serta meminta pergantian pegawai dengan alasan ada ketidakcocokan. Setelah memasuki satu tahun berdirinya Restauran Sunda tersebut, kepala koki kembali meminta kenaikan gaji dua kali lipat dengan alasan yang tidak masuk akal. Pada akhirnya, karena tuntutannya tidak dipenuhi, kepala koki tersebut mengundurkan diri. Pengunduran diri ini sebenarnya menimbulkan masalah baru pada Restaurant Sunda tersebut. Secara tidak langsung, kunci masakan Restauran Sunda tersebut ada pada resep yang dipegang oleh kepala koki yang keluar. Karena terjadi penurunan kualitas rasa lambat laun Restoran Sunda sepi pengunjung dan akhirnya tutup setelah bertahan selama enam bulan (Saputro, 2016). Secara tidak langsung apa dalam menciptakan rahasia dagang yaitu masakanmasakan restaurant sunda dan khususnya sambal hejo, head chef menggunakan sarana dan prasarana yang dimiliki oleh pemilik restaurant. Disisi lain dengan hubungan kerja yang ada antara pemilik restauran dan 
head chef, dapat dikatakan bahwa apa yang ada dalam restaurant tersebut menjadi milik pemilik restaurant. Sayangnya anggapan tersebut berbeda dengan yang dipahami oleh head chef. Rahasia dagang yang diciptkan oleh head chef kemudian di klaim murni milik head chef dan pemilik restaurant tidak memiliki wewenang atas resep tersebut. Kasus ini tidak diajukan tindakan hukum dengan tidak adanya perjanjian kerja dan kekuatan hukum yang jelas untuk menuntut kepemilikan resep. Undang-Undang Nomor 30 Tahun 2000 tidak menjelaskan mengenai aspek hukum dalam hubungan kerja suatu rahasia dagang dapat melekat pada penemu rahasia dagang atau pada pemilik usaha yang mempekerjakan penemu tersebut. Pemilik restauran Sunda dan head cheaf tidak memiliki perjanjian kerja menimbulkan sulitnya tindakan hukum untuk menuntut kepemilikan resep.

Kasus pelanggaran rahasia dagang yang kedua bermula dengan adanya 2 mantan karyawan PT General Food Industries (PT GFI) yang bernama Andreas Tan Giok San dan Rachmat Hendarto diduga melanggar perjanjian kerja sekaligus tanpa hak memberikan rahasia dagang kepada pesaing yaitu PT Bumi Tangerang Mesindotama (PT BTM) (Anonim, 2007). PT GFI merupakan perusahaan pengolah biji cokelat yang berlokasi di Dayeuh Kulot Bandung yang merupakan anak cabang perusahaan Petra Food Limited yang berpusat di Singapura. Sejenis dengan PT GFI, PT BTM juga bergerak di industri pengolahan biji cokelat. Andreas telah bekerja sejak 1995 sebagai roaster enginering, yang memiliki tugas tugasnya memastikan semua proses produksi sudah dilakukan sesuai standar. Andreas keluar dari PT GFI pada September 2005. Sementara itu, Rachmat bekerja pada tahun 1997 sebagai process enginering, dengan tugas utama mengawasi jalannya produksi. Rachmat keluar dari PT GFI pada tahun Juni 2005. Setelah Andreas dan Rachmat keluar dari PT GFI dan bekerja di PT BTM, mengingat posisi kedua karyawan tersebut di PT GFI sangat dekat dengan rahasia produksi yang dimiliki PT BTM, maka PT BTM menduga bahwa kedunya tanpa hak memberikan rahasia dagang kepada PT BTM. Selain itu, Andreas dan Rachmat juga dinilai tidak mematuhi surat pernyataan yang pernah ditandatanganinya di atas materai pada Mei 2001. Isi surat pernyataan tersebut antara lain:

1. Setia dan jujur terhadap perusahaan serta memegang teguh rahasia perusahaan;

2. Selama dua tahun setelah keluar dari perusahaan maka tidak diperkenankan untuk bekerja di perusahaan pesaing;

3. Apabila dilanggar akan di tuntut di pengadilan; 
Mengetahui tindakan dua mantan karyawan PT GFI yang melanggar aturan, PT GFI mengirimkan dua kali surat peringatan, namun tidak mendapat tanggapan dari pihak Andreas dan Rachmat. Pada akhirnya, PT GFI melaporkan kasus tersebut kepada kepolisian dengan tuduhan bahwa keduanya tanpa hak telah memberikan rahasia dagang dan mengingkari pernyataan yang pernah dibuat. Apa yang telah dilakukan oleh PT GFI sebenarnya telah benar dengan mengikat karyawannya dengan perjanjian kerja. Perjanjian kerja yang diberikan mengandung klausul kerahasiaan yang erat kaitannya dengan upaya perlindungan rahasia dagang. Selain itu juga diatur mengenai non competition clause. Klausul tersebut mengatur bahwa tenaga kerja setuju untuk tidak akan bekerja sebagai karyawan atau agen perusahaan yang dianggap sebagai pesaing atau bergerak pada bidang usaha yang sama untuk periode atau jangka waktu tertentu setelah tanggal pemberhentian atau pemutusan hubungan kerja (Chandra Kurniawan, 2010).

Kasus ketiga berdasarkan Putusan Mahkamah Agung Nomor 332 K/PID.SUS/2013. Kasus ini melibatkan Hi Pin (CV Tiga Putra Berlian) sebagai terdakwa dan John Satria Salim (CV Bintang Harapan) sebagai pemilik hak rahasia dagang. Keduanya merupakan pengusaha kopi bubuk. Hi Pin diduga mempengaruhi karyawan CV Bintang Harapan yang dipimpin oleh John Satria Salim untuk ikut bekerja bersamanya dengan memberi tawaran gaji dua kali lebih besar. Mulanya yang direkrut hanya satu karyawan bernama Noldhy Lagindawa yang merupakan karyawan bagian produksi dan pemasaran pabrik Kopi Bintang Harapan. Selanjutnya, Hi Pin juga meminta Noldhy untuk membujuk teman-teman lain yang bekerja di Pabrik Bintang Harapan untuk pindah bekerja bersama dirinya. Karyawankaryawan tersebut antara lain Parian bekerja di bagian produksi, Arsand bekerja di bagian produksi, Markum Yambese bekerja di bagian penggorengan dan pengepakan, dan Jumadi yang bekerja di bagian produksi dan pemasaran. Kasus rahasia dagang ini diproses hingga pengadilan negeri dan dalam proses memutuskan, hakim tidak saksama dalam melakukan pembuktian sehingga menyebabkan adanya judex facti atau hakim salah dalam menerapkan hukum. Adanya judex factie tersebut, kemudian tuntutan dari jaksa tidak dikabulkan oleh hakim dan PN Palu membebaskan Hi Pin serta memulihkan namanya. Namun pada akhirnya, setelah di ajukannya kasasi oleh jaksa, hakim memberikan putusan penjara 1 tahun 6 bulan dan denda sebesar Rp 5.000.000,00 (lima juta rupiah) dimana hakim meyakini perbuatan $\mathrm{Hi}$ Pin telah melanggar rahasia dagang yaitu memerintahkan mantan karyawan John 
Satria Salim untuk membuat mesin-mesin penggorengan dan produksi, serta memgambil kopi mentah, saringan kopi bubuk, plastik packing dari pabrik John Satria Salim yang kesemuanya merupakan rahasia dagang.

Perlindungan rahasia dagang sangat penting dilakukan dalam hubungan kerja antara pemilik dan karyawan (Situngkir, 2017). Untuk mencegah pengungkapan rahasia dagang, pemilik rahasia dagang seringkali membutuhkan perjanjian kerja atau kontrak kerja untuk memberikan alternatif perlindungan rahasia dagang (Garry, 1985). Kontrak kerja merupakan salah satu dari perjanjian untuk melakukan pekerjaan sebagaimana sesuai dalam Pasal 1601 KUHPerdata (Mahila, 2010). Sesuai dengan Pasal 1 angka 14 Undang-Undang Nomor 13 Tahun 2003 tentang Ketenagakerjaan perjanjian kerja adalah perjanjian antara pekerja/buruh dengan pengusaha atau pemberi kerja yang memuat syarat syarat kerja, hak, dan kewajiban para pihak. Maka dari itu, untuk memberikan perlindungan hukum rahasia dagang dalam perjanjian kerja harus memberikan kejelasan hak dan kewajiban bagi para pihak yang terkait dengan hak rahasia dagang, seperti pemilik rahasia dagang serta pihak ketiga penerima lisensi dengan karyawan. Selain itu, dalam kontrak kerja harus berlandaskan pada keadilan agar hak dan kewajiban masing-masing pihak terpenuhi secara optimal dan tidak berat sebelah. Definisi keadilan berdasarkan John Rawl berprinsip pada tiga hal yaitu kebebasan yang sama, perbedaan dan persamaan yang adil dalam kesempatan (John Rawls, 1985).

Pembahasan mengenai rahasia dagang dalam kaitannya dengan perjanjian kerja atau kontrak kerja sebelumnya telah dibahas dalam artikel Jurnal Ilmiah Universitas Batanghari Jambi Vol.10 No.3 Tahun 2010 dengan judul Perlindungan Rahasia Dagang Dalam Hubungannya Dengan Perjanjian Kerja (Mahila, 2010); dan artikel Lex Privatum, Vol.I/No.4/Oktober/2013 dengan judul Perlindungan Hukum Bagi Pemilik Rahasia Dagang (Ghiand Carllo Legrands, 2013). Dalam dua artikel tersebut hanya sebatas membahas mengenai cara perusahaan dalam mengelola dan mengontrol informasi rahasia perusahaan yang berpengaruh pada loyalitas pekerja dan memberikan perlindungan hukum bagi pemilik rahasia dagang. Sedangkan dalam artikel ini bertujuan untuk mengkaji lebih jauh mengenai urgensi kontrak kerja yang berkeadilan sebagai upaya perlindungan hukum rahasia dagang.

\section{B. Metode Penelitian}

Penelitian ini adalah penelitian hukum normatif. Data sekunder yang digunakan dalam penelitian ini adalah data sekunder 
yang berupa bahan hukum primer berupa peraturan perundang-undangan yaitu Undang-Undang Nomor 30 Tahun 2000 tentang Rahasia dagang; Undang-Undang Nomor 13 Tahun 2003 tentang Ketenagakerjaan dan bahan hukum sekunder yang meliputi literatur berupa artikel jurnal, buku teks, hasil penelitian dan laporan-laporan yang berkaitan dengan pokok permasalahan. Studi pustaka merupakan teknik pengumpulan data yang digunakan dalam penelitian ini, sementara teknik analisis data menggunakan metode penafsiran hukum.

\section{Hasil dan Pembahasan}

\section{Kelemahan rahasia dagang}

Selama ini rahasia dagang di Indonesia masih memiliki kelemahan yang salah satunya berhubungan dengan karyawan. Pelanggaran rahasia dagang yang terjadi karena karyawan membocorkan atau menggunakan hak rahasia dagang secara tanpa hak. Perlindungan hukum yang berkaitan dengan karyawan tidak di atur dalam Undang-Undang Rahasia Dagang Nomor 30 Tahun 2000 tentang Rahasia Dagang. Undang-Undang Rahasia Dagang hanya mengatur mengenai pemberian hak rahasia dagang yang dapat menghindari adanya persaingan curang dan pelanggaran rahasia dagang, Undang-Undang Nomor 30 Tahun 2000 tentang Rahasia Dagang mengatur adanya lisensi. Dalam pasal 1 point 5 menyatakan:

lisensi adalah izin yang diberikan oleh pemegang Hak Rahasia Dagang kepada pihak lain melalui suatu perjanjian berdasarkan pada pemberian hak (bukan pengalihan hak) untuk menikmati manfaat ekonomi dari suatu rahasia dagang yang diberi perlindungan dalam jangka waktu tertentu dan syarat tertentu.

Lisensi harus didasarkan dalam perjanjian lisensi sebagai dasar pelaksanaan pemberian lisensi dari pemilik hak kepada pihak ketiga.

Lisensi dalam Undang-Undang Rahasia Dagang diatur dalam Pasal 6 sampai dengan Pasal 10 yang berbunyi:

Pasal 6

Pemegang Hak Rahasia Dagang berhak memberikan Lisensi kepada pihak lain berdasarkan perjanjian Lisensi untuk melaksanakan perbuatan sebagaimana dimaksud dalam Pasal 4, kecuali jika diperjanjikan lain.

Pasal 7

Dengan tidak mengurangi ketentuan sebagaimana dimaksud dalam pasal 6, pemegang Hak Rahasia Dagang tetap dapat melaksanakan sendiri atau memberikan Lisensi kepada pihak ketiga untuk melaksanakan perbuatan sebagaimana dimaksud dalam Pasal 4, kecuali jika diperjanjikan lain.

Pasal 8 
(1) Perjanjian Lisensi wajib dicatatkan pada Direktorat Jenderal dengan dikenai biaya sebagaimana diatur dalam Undang-undang ini.

(2) Perjanjian Lisensi Rahasia Dagang yang tidak dicatatkan pada Direktorat Jenderal tidak mempunyai akibat hukum terhadap pihak ketiga.

(3) Perjanjian Lisensi sebagaimana dimaksud dalam ayat (1) diumumkan dalam Berita Resmi Rahasia Dagang.

\section{Pasal 9}

(1) Perjanjian Lisensi dilarang memuat ketentuan yang dapat menimbulkan akibat yang merugikan perekonomian Indonesia atau memuat ketentuan yang mengakibatkan persaingan usaha tidak sehat sebagaimana diatur dalam peraturan perundang-undangan yang berlaku.

(2) Direktorat Jenderal wajib menolak pencatatan perjanjian Lisensi yang memuat ketentuan sebagaimana dimaksud dalam ayat (1).

(3) Ketentuan mengenai pencatatan perjanjian Lisensi diatur dengan Keputusan Presiden.

Pasal 10

(1) Pencatatan pengalihan hak dan pencatatan perjanjian Lisensi Rahasia Dagang dikenai biaya yang jumlahnya ditetapkan dengan Peraturan Pemerintah.
(2) Ketentuan lebih lanjut mengenai persyaratan, jangka waktu, dan tata cara pembayaran biaya sebagaimana dimaksud dalam ayat (1) diatur dengan Keputusan Presiden.

(3) Direktorat Jenderal dengan persetujuan Menteri dan Menteri Keuangan dapat mengelola sendiri biaya sebagaimana dimaksud dalam ayat (1) dan ayat (2) berdasarkan peraturan perundangundangan yang berlaku.

Perjanjian merupakan bukti tertulis tersebut menjadikan dasar yang kuat adanya pemberian hak dan dapat sebagai upaya perlindungan dan mencegah terjadiya pelanggaran hak rahasia dagang. Perjanjian sebagai dasar adanya hubungan antar pemilik hak dan pihak ketiga penerima hak rahasia dagang. Sebenarnya, hubungan pemilik hak rahasia dagang tidak hanya terbatas pada penerima lisensi namun juga dengan karyawan. Hubungan dengan karyawan sering kali luput dari perlindungan dan menyebabkan banyak terjadi pelanggaran rahasia dagang. Karyawan merupakan faktor utama dalam sebuah usaha, dimana karyawan merupakan penggerak perusahaan yang harus mendapat kepastian hukum serta kesejahteraan (Wildan, 2017). Karyawan yang berperan langsung dalam penggunaan rahasia dagang memiliki banyak celah secara tanpa hak menggunakan hak rahasia dagang. Setiap 
kali karyawan yang berperan dalam menjaga rahasia dagang berhenti dari pekerjaan maka tanpa adanya hubungan kerja yang mengikat secara jelas dan kuat, rahasia dagang dapat dikhawatirkan akan hilang (Kopko, 1964). Sanksi perdata maupun sanksi pidana yang ada juga seakan tidak menjadi penting karena karyawan sering kali tidak paham akan adanya rahasia dagang pada pekerjaan yang mereka geluti. Aturan rahasia dagang Indonesia tidak mengatur secara khusus mengenai perlindungan karyawan, sehingga menjadikan salah satu kelemahan aturan rahasia dagang yang dapat menimbulkan permasalahan hukum. Terbukti dari adanya kasus pelanggaran rahasia dagang yang terjadi di Indonesia melibatkan karyawan.

\section{Urgensi Kontrak Kerja}

\section{a. Syarat-Syarat Kontrak Kerja}

Permasalahan rahasia dagang yang ada tidak dapat dipungkiri bahwa sebagian besar dipengaruhi dari adanya perbuatan karyawan yang melakukan kegiatan membocoran menguasai atau menyalahgunakan rahasia dagang secara tanpa hak. Aturan Indonesia yaitu pada Undang-Undang Nomor 30 Tahun 2000 tentang Rahasia Dagang yang hanya mengatur mengenai pemberian hak lisensi kepada pihak ketiga sebagai upaya untuk menghindari persaingan usaha dan dapat terciptanya saling menguntungkan dari adanya kegiatan komerisil royalty yang diberikan. Penerapan adanya perjanjian lisensi yang dijelaskan dalam UndangUndang Rahasia Dagang, seharusnya juga diterapkan sebagai upaya perlindungan hukum rahasia dagang pada hubungan kerja. Hubungan kerja antara pemilik rahasia dagang serta pihak lisensi dengan karyawan yang lupa untuk diperhatikan. Hubungan kerja dengan karyawan tersebut sebenarnya sangat memiliki ancaman yang lebih mengkhawatirkan. Contoh permasalahan yang telah dipaparkan dalam pendahuluan menjadikan bukti bahwa terjadinya pelanggaran rahasia dagang disebabkan oleh karyawan. Sebagai upaya perlindungan hukum rahasia dagang adalah dengan cara memberikan pengaturan yang mendasarkan kontrak kerja. Subyek dari terbentuknya kontrak kerja meliputi adanya pemilik rahasia dagang atau pihak ketiga penerima lisensi dan karyawan yang masing-masing pihak tentu memiliki kepentingan. UndangUndang Nomor 13 Tahun 2003 tentang Ketenagakerjaan dalam Pasal 1 menyatakan bahwa perjanjian kerja adalah perjanjian antara pekerja dengan pengusaha atau pemberi kerja yang memuat syarat-syarat kerja, hak dan kewajiban para pihak.

Syarat-syarat yang harus dipenuhi dalam sahnya kontrak kerja sesuai dengan Pasal 52 ayat (1) Undang-Undang Nomor 13 Tahun 2003 tentang Ketenagakerjaan terdiri dari:

\section{1) Kesepakatan kedua belah pihak}


Kesepakatan kedua belah pihak yang sering disebut kesepakatan bagi pihak-pihak yang mengikatkan dirinya untuk mengadakan kontrak kerja harus sepakat, seia sekata mengenai hal-hal yang tertuang dalam kontrak. Tidak terdapat pemaksaan kehendak dan pihak karyawan menerima apa yang ditawarkan serta pihak pemberi kerja menerima sebagai pekerja. Hal tersebut mendasarkan bahwa terjadinya hubungan kerja tidak terjadi penipuan (dwang), paksaan (dwaling), dan kekhilafan (bedrog) dalam kesepakatan kedua belah pihak.

2) Kemampuan atau kecakapan melakukan perbuatan hukum

Kemampuan atau kecakapan kedua belah pihak yang membuat perjanjian maksudnya pihak pekerja maupun pengusaha cakap membuat perjanjian. Seseorang dipandang cakap membuat perjanjian jika yang bersangkutan telah cukup umur. Ketentuan hukum ketenagakerjaan memberi batasan umur minimal 18 Tahun bagi seseorang dianggap cakap membuat perjanjian kerja, sebagaimana diatur didalam ketentuan Pasal 1 ayat (26) Undang-undang No.13 Tahun 2003 tentang Ketenagakerjaan. Pasal 69 Undang-Undang No.13 Tahun 2003 tentang Ketenagakerjaan memberi pengecualian bagi anak yang berumur 13 Tahun sampai dengan umur 15 Tahun untuk melakukan pekerjaan ringan sepanjang tidak menggangu perkembangan dan kesehatan fisik, mental, dan sosial. Selain itu juga seseorang dikatakan akan cakap membuat suatu perjanjian kerja jika seseorang tersebut tidak dibawah pengampuan yaitu tidak terganggu jiwanya/sehat.

3) Adanya pekerjaan yang diperjanjikan

Adanya pekerjaan yang diperjanjikan, artinya bahwa adanya hal tertentu yang diperjanjikan. Pekerjaan yang diperjanjikan merupakan objek dari perjanjian kerja antara pemberi kerja/pengusaha dengan pekerja/buruh, yang akibat hukumnya melahirkan hak dan kewajiban para pihak.

4) Pekerjaan yang diperjanjikan tidak boleh bertentangan dengan ketertiban umum, kesusilaan, dan ketentuan peraturan perundang-undangan yang berlaku

Pada dasarnya obyek perjanjian (pekerjaan) harus halal yang artinya bahwa tidak boleh bertentangan dengan undangundang, ketertiban umum, dan kesusilaan. Jika pekerjaan yang diperjanjikan merupakan salah satu unsur perjanjian kerja yang harus disebutkan secara jelas.

Keempat syarat kerja tersebut bersifat kumulatif yang artinya bahwa harus dipenuhi semuanya baru dapat dikatakan bahwa perjanjian tersebut sah. Syarat kemauan bebas kedua belah pihak dan kemampuan atau kecakapan kedua belah 
pihak dalam membuat perjanjian lebih bersifat syarat subyektif karena menyangkut mengenai orang yang membuat perjanjian. Syarat sahnya adanya pekerjaan yang diperjanjikan dan pekerjaan yang diperjanjikan harus halal disebut sebagai syarat obyektif karena menyangkut obyek perjanjian. Apabila syarat obyektif tidak dipenuhi, maka perjanjian itu batal demi hukum artinya bahwa dari semula perjanjian tersebut dianggap tidak pernah ada. Jika yang tidak dipenuhi merupakan syarat subyektif, pihak-pihak yang tidak memberikan persetujuan secara tidak bebas, atau orang tua/wali atau pengampu bagi yang tidak cakap membuat perjanjian dapat meminta pembatalan perjanjian kepada hakim. Dengan demikian, perjanjian tersebut mempunyai kekuatan hukum selama belum dibatalkan oleh hakim (Lalu Husni, 2014)

Perjanjian kerja sesuai dengan Pasal 54 Undang-Undang Nomor 13 Tahun 2003 tentang Ketenagakerjaan secara umum sekurang-kurangnya harus memuat (Mahila, 2010):

a. Nama, alamat perusahaan, dan jenis usaha;

b. Nama, jenis kelamin, umur, dan alamat pekerja;

c. Jabatan atau jenis pekerjaan;

d. Tempat pekerjaan;

e. Besarnya upah dan cara pembayaran; f. Syarat-syarat kerja yang memuat hak dan kewajiban pengusaha dan pekerja;

g. Mulai dan jangka waktu berlakunya perjanjian kerja;

h. Tempat dan tanggal perjanjian kerja dibuat;

i. Tanda tangan para pihak dalam perjanjian kerja.

\section{b. Kontrak Kerja yang Berkeadilan}

Sebagai upaya perlindungan hukum rahasia dagang dalam kontrak kerja yang berkeadilan didalamnya harus mengatur mengenai hal-hal yang dapat mencegah dan memberikan perlindungan hukum rahasia dagang. Klausul-klausul yang diatur di dalam kontrak kerja harus memuat beberapa unsur yaitu:

\section{1) Kewajiban untuk menjaga kerahasiaan; \\ Pengaturan menjaga kerahasiaan} sangat utama dalam upaya menjaga rahasia dagang. Secara umum kerahasiaan berkaitan dengan kepercayaan, karena itu pula rahasia dagang sebagai salah satu faktor untuk menjaga kepercayaan publik. Mengingat kerahasiaan tersebut utamanya untuk menjaga kepercayaan masyarakat, dengan demikian prinsip kerhasiaan dalam sebuah kegiatan usaha khususnya dalam rahasia dagang adalah bertujuan untuk melindungi informasi rahasia tersebut agar tidak dipergunakan oleh pihak lain yang tidak berhak (Hidayat, 2016). Sifat rahasia dagang sesuai dengan Pasal 1 ayat (1) yang dapat 
dikatakan sebagai rahasia dagang apabila terdapat kerahasiaan yang tidak diketahui oleh umum. Pasal 3 ayat (2) UndangUndang Rahasia Dagang juga menegaskan tentang sifat kerahasiaan dari rahasia dagang dimana menyatakan Informasi dianggap bersifat rahasia apabila informasi tersebut hanya diketahui oleh pihak tertentu atau tidak diketahui secara umum oleh masyarakat. Kerahasiaan tersebut harus diminimalisir agar kemudian tidak menjadi bersifat umum. Karyawan baik dalam hubungan langsung dengan pemilik rahasia dagang maupun dengan pihak ketiga rahasia dagang merupakan pihak yang berhubungan langsung dengan rahasia dagang wajib untuk diatur agar tidak terjadi pelanggaran rahasia dagang. Seperti pada kasus yang terjadi dalam pabrik kopi bubuk, dimana karyawan dari CV Bintang Harapan dibujuk dan ditawari gaji dua kali lipat apabila berpindah di CV Tiga Putra Berlian. Tidak terdapat kontrak kerja untuk menjaga kerahasiaan menjadi salah satu kelemahan rahasia dagang dapat mudah berpindah kepada perusahaan pesaing. Maka dari itu dalam kontrak kerja baik dalam hubungan kerja dengan pemilik rahasia dagang secara langsung maupun dengan pihak ketiga peerima lisensi harus memperhatikan dan mencantumkan klausul kewajiban menjaga kerahasiaan sebagai klausul pokok.

\section{2) Batasan penggunaan rahasia dagang;}

Dengan adanya kewajiban untuk menjaga kerahasiaan, pastilah timbul penggunaan rahasia dagang yang dilimpahkan kepada karyawan. Batasan penggunaan rahasia dagang yang harus ditegaskan agar selanjutnya tidak menimbulkan masalah. Maksud batasan penggunaan rahasia dagang disini kemudian melindungi seluruh lingkup rahasia dagang. Pasal 2 Undang-Undang Nomor 30 Tahun 2000 tentang Rahasia Dagang menyatakan lingkup perlindungan rahasia dagang meliputi informasi tentang metode produksi, metode pengolahan, metode penjualan atau informasi lainnya di bidang teknologi dan atau bisnis yang bernilai ekonomi dan tidak diketahui oleh masyarakat umum. Karyawan yang melakukan penggunaan rahasia dagang tersebut harus secara jelas diatur apa saja yang menjadi batas-batas hak penggunaan rahasia dagang. Tujuan kontrak sebagai alternarif untuk melindugi rahasia dagang tidak hanya data dan informasi yang berkatian dengan rahasia dagang namun juga termasuk dalam pengalaman teknik terkait dengan proses-proses pengolahan, perlengkapan, peralatan, bahan-bahan, tata cara pengoperasian, tata cara pengendalian mutu, tata cara keamanan, dan terkait dengan informasi mengenai formula- 
formula yang memiliki nilai komersial yang tinggi (Gerungan, 2016).

\section{3) Proporsi yang adil antara pencipta dan pemegang rahasia dagang;}

Kontrak kerja juga sangat penting dalam mengatur kepemilikan hak yang berhubungan dengan temuan rahasia dagang oleh karyawan dalam posisi terdapat hubungan kerja yang mengikat kedua belah pihak. Seperti kasus yang terjadi pada sebuah restaurant Sunda di Bintaro Jaya Jakarta Selatan bahwa pemilik restaurant di rugikan karena resep yang menjadi pokok metode produksi berdirinya usaha tersebut dalam penguasaan head chef. Dengan adanya kasus tersebut tentu kita harus memberikan perlindungan hukum rahasia dagang yang tepat. Berdasarkan pada pengertian rahasia dagang sendiri tentu kita dapat melihat bahwa yang dimaksud sebagai pemilik rahasia dagang ialah seseorang yang menjaga informasi yang tidak diketahui oleh umum di bidang teknologi dan/atau bisnis, mempunyai nilai ekonomi karena berguna dalam kegiatan usaha, dan dijaga kerahasiaan. Dari pengertian tersebut maka kita ketahui bahwa head chef dapat dikatakan pemilik rahasia dagang yang sebenarnya karena ia telah menjaga rahasia dagang tersebut, namun dalam hubungan pekerjaan yang demikian head chef secara tanpa sadar telah menggunakan sarana dan prasarana yang ada dalam restaurant tempat ia bekerja. Dalam hubungan kerja yang demikian, kontrak kerja berperan dalam memberikan jalan tengah untuk tercapainya keadilan. Perjanjian kerja tersebut harus berprinsip dasar adanya keadilan sehingga dapat menyejahterakan baik pemilik usaha dan karyawan yang berperan sebagai penemu rahasia dagang. Contoh dari adanya pelaksanaan kontrak yang berprinsip keadilan menyejahterakan kedua belah pihak adalah dengan menerapkan apabila karyawan menemukan penemuan baru terkait rahasia dagang maka terdapat imbalan yang sebelumnya ditentukan dalam kontrak. Dapat disimpulkan bahwa pemilik restaurant memberikan upah khusus guna menjadikan hak milik rahasia dagang dari penemu rahasia dagang tersebut beralih. Atau dapat juga dengan penerpan bagi hasil antara kedua belah pihak agar keduanya tetap mendapat proporsi yang seimbang. Namun perlu digaris bawahi bahwa apabila penemu yang merupakan karyawan dari pemilik usaha tersebut keluar, maka tidak berhak untuk membawa rahasia dagang yang diketatuhi ke tempat kerja barunya.

\section{4) Memuat non-competition clause;}

Kasus PT GFI dan PT BTM yang sebelumnya telah diketahui terdapat pembatasan untuk melakukan mobilitas pada perusahaan pesaing selama 2 tahun dapat dikatakan sebagai perbuatan tersebut sesuai dengan non-competition clause. Secara lebih jelas bahwa yang disebut dengan non-competition clause adalah 
klausul yang mengatur bahwa tenaga kerja setuju untuk tidak akan bekerja sebagai karyawan atau agen perusahaan yang dianggap sebagai pesaing atau bergerak pada bidang usaha yang sama untuk periode atau jangka waktu tertentu setelah tanggal pemberhentian atau pemutusan hubungan kerja. Pencantuman klausula tersebut seringkali dilakukan dalam perjanjian kerja dimana perusahaan tersebut merupakan perusahaan besar yang memiliki pesaing sehingga rawan terjadi persaingan usaha (Amalia, 2011). Penerapan non-competition clause sebenarnya bertentangan dengan Undang-Undang Dasar 1945, UndangUndang ketenegakerjaan dan Hak Asasi Manusia. Berdasarkan prinsip hukum di Indonesia, non-competition clause bertentangan dengan prinsip dasar dalam Undang-Undang Dasar 1945 menyebutkan bahwa setiap orang berhak untuk bekerja serta mendapat imbalan dan perlakuan adil dan layak dalam hubungan kerja, UndangUndang Ketenagakerjaan dimana secara prinsip, Undang-Undang Nomor 13 Tahun 2003 Ketenagakerjaan Pasal 31 memberikan hak dan kesempatan yang sama untuk tenaga kerja untuk memilih, mendapatkan atau pindah pekerjaan dan memperoleh penghasilan yang layak baik di dalam maupun di luar negeri. Dan Undang-Undang Nomor 36 Tahun1999 tentang Hak Asasi Manusia Pasal 38 Undang-Undang HAM menyebutkan bahwa setiap orang berhak dengan bebas memilih pekerjaan yang disukainya dan berhak pula atas syaratsyarat ketenagakerjaan yang adil.

Namun dalam rangka memberikan perlindungan hukum rahasia dagang pantaslah terdapat hal tersebut karena kekhawatiran dari kalangan pengusaha atau pemberi kerja bahwa pekerja tersebut akan membocorkan rahasia atau memberikan pengetahuannya yang mungkin bersifat rahasia dan memiliki nilai ekonomis kepada perusahaan baru tempat ia bekerja yang merupakan perusahaan pesaing yang mencoba mengambil keuntungan dari pengetahuan si pekerja terhadap perusahaan lama tempat pekerja tersebut bekerja. Meski terdapat pertentangan secara tersirat dengan Undang-Undang Dasar 1945, UndangUndang Ketenagakerjaan serta UndangUndang Hukum Hak Asasi Manusia, Indonesia memang tidak secara tegas mempunyai aturan yang melarang atau memperbolehkan non-competition clause dicantumkan dalam perjanjian kerja. Sebagai alternatif terbaik untuk memberikan perlindungan hukum rahasia dagang noncompetition clause dapat diterapkan dalam kontrak. Akan tetapi untuk dapat diterapkan dalam perjanjian kerja di Indonesia harus menafsirkan non-competition clause secara adil dan tidak menimbulkan kesenjangan sosial. 


\section{5) Klausul perjanjian yang harus berlandaskan prinsip keadilan}

Prinsip keadilan yang tidak berat sebelah pada masing-masing pihak merupakan point utama menciptakan kontrak kerja yang baik. Definisi keadilan atau adil memiliki makna bahwa adil memanglah tidak harus sama, namun berdasarkan teori keadilan yang disampaikan oleh John Rawl bahwa keadilan berprinsip pada tiga hal yaitu kebebasan yang sama, perbedaan dan persamaan yang adil dalam kesempatan. Kebebasan disini dimaksudkan dalam melakukan suatu hubungan kontrak. Dalam membuat sebuah kontrak, bebas dalam menentukan isi dari kontrak dan segala yang berkaitan dengan kontrak karena adanya asas kebebasan berkontrak (Anand, 2011). Asas kebebasan berkontrak tersebut harus didasarkan pada asas keseimbangan yang merupakan pelaksanaan dari prinsip itikad baik. Realita yang terjadi dalam masyarakat menunjukan bahwa kebebasan tidak dapat sepenuhnya terwujud karena adanya perbedaan kondisi dari pemilik, karyawan, licensee (pihak ketiga penerima lisensi). Adanya perbedaan tersebut harus dapat diberikan kesempatan yang sama untuk mencapai kepentingannya dengan mengambil titik tengah sebagai wujud keadilan. Pada dasarnya kepentingan tersebut harus dipenuhi sesuai proporsinya sehingga sama-sama dapat mencapai kesejahteraan (Fattah, 2013).

Pengaturan klausul-klausul tersebut dapat secara tegas mengatur perlindungan hukum rahasia dagang. Sebelum karyawan mulai bekerja, terlebih dahulu diminta untuk menandatangani kontrak kerja yang berisi persyaratan untuk menjaga Rahasia Dagang. Apabila karyawan terbukti melanggar kontrak kerja tersebut dengan menyebarkan ataupun membocorkan informasi metode, strategi, atau pengetahuan, yang dijaga kerahasiaannya akan dikenakan sanksi peringatan, menutup mereka bisnis dan membayar kompensasi, hingga membawa gugatan ke Pengadilan (lestari dkk, 2017). Dalam pembuatan kontrak kerja tidak mengesampingkan asas kebebasan berkontrak yang mengatur pembuatan kontrak bebas untuk mengatur apa saja yang ada dalam kontrak. Namun dalam kontrak kerja sebagai upaya perlindungan hukum rahasia dagang ini minimal mengatur lima hal yang sudah dijelaskan sebelumnya.

Urgensi dari adanya kontrak kerja jelas terlihat bahwa apabila kontrak kerja dapat diterapkan dengan di dalamnya minimal memuat lima point klausul-klausul tersebut maka perlindungan hukum rahasia dagang jelas akan terjaga. Sehingga pelanggaran rahasia dagang yang selama ini banyak terjadi karena dipicu oleh karyawan tidak lagi terjadi. Apabila masih terjadi pelanggaran rahasia dagang setelah terdapat 
kontrak kerja telah terdapat hukum tertulis yang kuat sebagai perlindungan hukum dari rahasia dagang tersebut.

\section{Simpulan}

Berdasarkan kajian di atas, dapat disimpulkan bahwa permasalahan rahasia dagang yang ada di Indonesia pada dasarnya melibatkan pelanggaran yang dilakukan karyawan. Kesadaran karyawan melaksanakan kewajiban melindungi rahasia dagang tidak dapat dilakukan karena tidak ada aturan kontrak kerja yang mengatur, di samping itu peraturan rahasia dagang belum mengatur perlindungan hukum karyawan yang memiliki hubungan langsung dengan rahasia dagang. Urgensi kontrak kerja yang berkeadilan sebagai upaya perlindungan hukum rahasia dagang sangat tepat dimana di dalamnya harus tercantum Klausulklausul untuk mengatur perlindungan hukum rahasia dagang, diantaranya meliputi: (1) Kewajiban untuk menjaga kerahasiaan; (2) Batasan penggunaan rahasia dagang; (3) Proporsi yang adil antara pencipta dan pemegang rahasia dagang; (4) Memuat non-competition clause;(5) Klausul perjanjian yang harus berlandaskan prinsip keadilan. Untuk itu, perlu diatur kewajiban adanya kontrak kerja yang mencantumkan 5 klausul perlindungan rahasia dagang dalam kontrak kerja sebagai upaya perlindungan hukum rahasia dagang di dalam UndangUndang Rahasia Dagang.

\section{DAFTAR PUSTAKA}

Amalia, R. (2011). Non-Competition Clause dalam Perjanjian Kerja. Yuridika, 26(2), 118.

Anand, G. (2011). Prinsip Kebebasan Berkontrak dalam Penyusunan Kontrak. Yuridika, 26(2), 91.

Anonim. (2007). Selembar surat pernyataan Menjadi Perkara. Majalah Tempo.

Chandra Kurniawan. (2010). Menyoal NonCompetition Clause dalam Perjanjian. Retrieved from http://www.hukumonline.com/berita/b aca/lt4be0fde6504fa/menyoalinoncompetition-clausei-dalamperjanjian-kerja-broleh-chandrakurniawan-

Fattah, D. (2013). Teori Keadilan Menurut John Rawls. Jurnal TAPIs, 9(2), 4344.

Garry, P. (1985). The Relationship Between Employment Agreements and Trade Secret Litigation in Minnesota: The Evolution of Trade Secret Law from Cherne to Electro-Craft. William Mitchell Law Review, 11(2), 501.

Gerungan, A. E. (2016). Perlindungan Hukum terhadap Rahasia Dagang ditinjau dari Aspek Hukum Perdata 
dan Pidana di Indonesia. Jurnal Hukum Unsrat, 22(5), 79.

Ghiand Carllo Legrands. (2013). Perlindungan Hukum Bagi Pemilik Rahasia Dagang. Lex Privatum, 1(4), 160.

Hidayat, A. (2016). Penggunaan Informasi Yang Bersifat Rahasia Oleh Karyawan Kepada Perusahaan Sesama Peserta Tender Dihubungkan Dengan Prinsip Kerahasiaan Dan Undangundang Nomor 30 Tahun 2000 Tentang Rahasia Dagang Juncto UndangUndang Nomor 13 Tahun 2003 Tentang Ketenagake. Jurnal Justisi Ilmu Hukum ISSN, 1(1), 54.

John Rawls. (1985). Justice as Fairness: Political not Metaphysical. Philosophy and Public Affairs, 14(3), 235. https://doi.org/10.1177/106689691350 9009

Kopko, A. J. (1964). Protection of Trade Secrets in the Employer- Employee Relationship. Notre Dame Law Review Article, 39(2), 200.

Lalu Husni. (2014). Pengantar Hukum Ketenagakerjaan Indonesia (edisi revi). Depok: Raja Grafindo Persada.

Mahila, S. (2010). Perlindungan Rahasia Dagang dalam Hubungannya dengan Perjanjian Kerja. Jurnal Ilmiah Universitas Batanghari Jambi, 10(3), 20.

Mustikarini, I. D. (2016). Perlindungan
Hukum Rahasia Dgang Terhadap Masyarakat Ekonomi Asean. Perspektif Hukum, 16(1), 77.

Paat, yenni lewis. (2013). Penyelesaian Sengketa Rahasia Dagang Menurut Hukum Positif Indonesia. Lex et Societatis, I(3), 34.

Saputro, A. D. (2016). The Death of Franchise penyebab matinya waralaba dan solusinya. Jakarta: Elex Media Komputindo.

Situngkir, C. M. (2017). Perjanjian Rahasia Dagang dalam Bisnis Pizza. Universitas Lampung.

Wildan, M. (2017). Perlindungan Hukum Tenaga Kerja Kontrak Dalam Perjanjian Kerja Waktu Tertentu Berdasarkan Undang-Undang No. 13 Tahun 2003 Tentang Ketenagakerjaan. Jurnal Hukum Khaira Ummah, 12(4), 834. 